\title{
Tailoring MBA (Software Enterprise Management) Curriculum: To Meet India’s Growing IT Challenges
}

\author{
Rakesh K. Singh, Centre for Development of Advanced Computing, rksingh@cdacnoida.in \\ Abhijit Sen, Kwantlen University College, abhijit.sen@kwantlen.ca
}

\begin{abstract}
With India's economic growth creating a need for skilled human capital, schools are tailoring their curriculum to create a new generation of professionals who can face the emerging challenges of globalization and competition with confidence. The traditional MBA curriculum has to be redesigned to suit today's needs, which require that students be provided a balanced exposure to the latest skills in Information Technologies (IT) supported by management disciplines. The MBA (Software Enterprise Management) program at the Centre for Development of Advanced Computing (C-DAC), Noida, India is designed to address the specific Management and Information Technology (IT) needs of the software industry in India. This paper provides an overview of the unique MBA (Software Enterprise Management) program curriculum and discusses the approach used in integrating ERP software in the curriculum.
\end{abstract}

Keywords: Information Technology (IT), Enterprise Resource Planning (ERP)

\section{INTRODUCTION}

With India's rapid economic expansion and the emerging opportunities in such areas as Information and Communications Technologies, Business and Knowledge Process Outsourcing, higher education is viewed as an important instrument for economic security and mobility. The current climate of globalization and liberalization and the dynamic economic growth of recent years have created unique and varied challenges for institutes of higher education in India, who are striving to redesign and refocus their curriculum to suit needs of industries. The Centre for Development of Advanced Computing (C-DAC) is a national initiative of the Government of India, Ministry of Communications \& IT, to mobilize human and technical resources in order to attain technological advancement in the ever evolving arena of Information Technology for the benefit of masses.

In its endeavor to integrate research and education and to meet the ever growing demand for professionally qualified and highly skilled technical manpower, CDAC Noida offers a variety of specialized courses covering crucial domains of the IT industry. These include:

- Post Graduate Education Programs like MBA (Software Enterprise Management), M.Tech. (CSE), M.Tech. (IT), M.Tech. (VLSI Design), MCA, in affiliation with the GGS Indraprastha University, Delhi.

- Non-Formal Education Programs leading to specialization in the area of ERP, Advanced Computing, Embedded System \& VLSI Design, System Administration, Wireless Technologies \& Applications, Database Administration, Red Hat Enterprise Linux, Geographic Information System \& Remote Sensing, Enterprise Network Management, e-Learning, etc

The MBA (Software Enterprise Management) program launched at Centre for Development of Advanced Computing (C-DAC), Noida, aims to create a new breed of professionals who can face with confidence emerging technical and managerial challenges. The program is approved by All India Council of Technical Education (AICTE), New Delhi and is affiliated with Guru Gobind Singh Indraprastha University, Delhi.

The paper describes an overview of the MBA (Software Enterprise Management) program, and discusses the strategies used in delivering the course. The curriculum is designed and delivered to make academic theory relevant through exercises and assignments normally encountered in a real world environment.

\section{PROGRAM OBJECTIVES}

The MBA (Software Enterprise Management) program is conceived, designed and structured as a Two Year Full Time Program to address the specific Management and Information Technology (IT) needs of the software industry in India and globally for software management professionals. This program aims at preparing specialized professionals for 
undertaking software projects with emphasis on business skill blended with software development technologies and Enterprise Resource Planning (ERP). The benefits and roles of using ERP software in business and information technology curriculum has been extensively discussed in literatures [1].The issues and challenges of integrating ERP into school curriculum have been articulated in [2].The approaches for incorporating enterprise system software into the curriculum have been proposed in [3].

The main objectives of the program are:

- $\quad$ To provide graduates with a strong technical background, as well as managerial skills to undertake software projects

- $\quad$ To enhance the decision-making skills and administrative competence needed for practicing managers to identify issues and solve problems

- $\quad$ To prepare students to manage and lead teams in an increasingly complex and dynamic global business environment

- $\quad$ To enhance both applied and conceptual knowledge that is relevant to management

- To instill knowledge of ERP and other tools for productivity enhancement and decision making

\section{PROGRAM FEATURE}

The program has been conceptualized around 8 different layers. Each layer consists of a set of core courses which are mandatory and a few elective courses. These courses are distributed over four semesters. In addition to the core and elective courses, participants are required to undertake mandatory project(s) in order to gain domain experience. The program layers have been identified after intensive consultations and feedback from leading professionals in industry, academia, and other institutions.

\section{Program Layers Description}

The following 8 layers form the core of the new curriculum:

\section{i) Layer 1:Management Practices}

The focus of this layer is to provide technical professionals with equally strong managerial skills needed for decision making in complex and dynamic business scenarios.

ii) Layer 2: Technology and Innovation Management in the Internet Economy
Students gain an understanding of the challenges of operating in the internet economy. Students are also prepared with evolving global practices, WTO guidelines for products \& services and intellectual property rights.

\section{iii) Layer 3: Software Engineering Principles and Practices}

This layer aims at developing strong analytical skills to understand the business processes and designing the complex software systems. Students work with tools for managing software development, analyzing and modeling software artifacts, assessing and controlling quality, and for ensuring a disciplined, controlled approach to software evolution and reuse.

\section{iv) Layer 4: Modern Programming Language Concepts and Interpretations}

Programming languages assume significance for the development, customization, and configuration of new and existing applications. The participants are equipped with the programming language concepts, evolving frameworks, and open source architectures that are in widespread use today.

\section{v) Layer 5: Enterprise-wide Analysis using databases and Data Warehousing Techniques}

Information Management plays a critical role in almost all areas, where computers are used. Students are taught to use tools and techniques for organizing, transforming, and presenting information to solve business decision problems.

\section{vi) Layer 6: Software Project Management in Networking Environment}

Quality, schedule, and cost are the important challenges for managing any software project. Students are prepared to plan for software projects that involve estimation of size and effort for project delivery, project scheduling, resource allocation, configuration control, change management, project risks etc.

\section{vii) Layer 7: Enterprise Resource Planning and Logistics Management}


In the ever-growing integrated business environment, flexibility to respond to changing business requirements, the ability to take informed management decisions, and need to analyze cost and revenues on a product or customer basis are demanded. Students are acquainted with the latest Enterprise Resource Planning (ERP) tools to manage enterprise-wide information.

\section{viii) Layer 8: e-Biz : Harnessing Opportunities in e-market}

This layer prepares the students to understand how marketing goals are to be realized through the Internet. Students are introduced to customer relationship management, e-procurement, and egovernance concepts.

\section{COURSE STRUCTURE}

The course structure for The MBA (Software Enterprise Management) is shown in Table 1 Appendix A. The curriculum focuses on problem solving, working projects, continuous appraisal, and action learning. It provides technical professionals with more industry perspective and the knowledge and tools required to succeed in this environment. The program covers core and elective courses. The core courses of the program are designed to provide participants rigorous foundations in the rudiments of various disciplines of Management and Information Technology with strengths in entrepreneurship.

Elective courses are designed for specialization in Human Resource, Finance, Marketing, Production, Planning, Logistics and Technical/Administration modules.

Project Work/Dissertation is intended to provide the students an opportunity to attain specialization in an area of study covered in the program. Each student will have to develop a project based on his/her area of specialization. Project work starts on $3^{\text {rd }}$ semester and continue up to semester 4, when students will implement the project in the ERP environment.

C-DAC has joined the SAP University Alliances program in collaboration with SAP Labs India Pvt. Ltd, a leading ERP software supplier. Through this alliance, SAP is providing the necessary software and support to be used in the integration of information technology into the curricula.

Students receive hands on training in the ERP tools through Industry Projects.

\section{Admission Process}

Admission to the MBA (Software Enterprise Management) Program is made on the basis of the Common Entrance Test (CET). Students meeting the following criteria will be eligible to appear in the CET.

\section{Eligibility Criteria}

MCA with minimum of $60 \%$ marks

B.E/ B. Tech with minimum of $60 \%$ marks, M. Sc. (CS), M. Sc. (IT), M. Sc. (Electronics) with minimum of $60 \%$ marks

The final Merit List for admission is prepared on the basis of candidate's performance in the Common Entrance Test (CET).

\section{MEETING NEEDS OF CORPORATE INDIA}

Globalization, diversification and marketplaces pressures today have forced structural changes in Indian organizations, making economic processes more complex. Every firm struggles to reengineer itself through product and process innovation and use of the information highway to reduce both costs and time to market, while improving product quality and capability. Using business management practice and Information technology the corporate world today utilizes widely used Enterprise Resource Planning (ERP) tool to integrate company's core business processes that allows for better decision making and strategic planning and to attain its corporate objectives.

$83 \%$ of students of the current graduating class have already been offered placements through campus recruitment in reputed national and international organizations. The specialization and placement details of the students are shown in Table 2, Appendix A. As is evident, this need based and relevant MBA (Software Enterprise Management) Curriculum has provided students with improved employment opportunities in high technology sectors.

The MBA (Software Enterprise Management) curriculum is equipping MBA students for the needs of Indian and global industries with the knowledge and diverse skills required to manage the entire business process. By offering quality management and information technology courses with substantial Enterprise Resource Planning (ERP) exposure the MBA (Software Enterprise Management) curriculum endeavors to provide high quality education to meet the demands of corporate India. 


\section{CONCLUSIONS}

The authors have presented the MBA (Software Enterprise Management) Program curriculum based on 8 layers approach as shown in Table 3 Appendix A. The design of this unique curriculum in India provides students with systematic and gradual exposure of important managerial and business issues integrated with the increasing role Information Technology is playing in various industrial sectors in India. The MBA (Software Enterprise Management) Program primarily aims to prepare the students for industry by exposing them to latest technology and tools used in current business scenario whereby students learn to configure and map various business processes of the company pertaining to core functionalities like Financial Accounting, Sales, Manufacturing, and Human Resources in an integrated manner to drive the company towards improved productivity. SAP ERP systems provide a wide-ranging teaching tool for business and for information systems and are used effectively in the program to support many of the concepts covered in the curriculum.

\section{REFERENCES}

1. Becerra-Fernandez, I., Murphy, K.E. and Simon, S.J. (2000) 'Enterprise resource planning: integrating ERP in the business school curriculum', Communications of the ACM, April, Vol. 43, No. 4, pp.39-41.

2. Bradford, M., Vijayaraman, B.S. and Chandra, A. (2003), "The Status of ERP Integration in Business School Curricula: Results of a Survey of Business Schools." Communications of the Association of Information Systems, Vol. 12, pp. 437-456.

3. Springer, M.C., Ross, S.C. and Human, N. (2007) 'Integrating ERP across the curriculum: a phased, three-tiered approach', Issues in Information Systems April, Volume VIII, No 1, pp.84-90. 


\section{Appendix A:}

Table 1: Course Structure: MBA (Software Enterprise Management)

\begin{tabular}{|c|c|}
\hline First Semester & Second Semester \\
\hline Management Functions \& Organizational Behaviour & Business Research \\
\hline Business Communication & Human Resource Management \\
\hline Financial and Management Accounting & Financial Management \\
\hline Quantitative Methods for Decision Making & Business Environment \\
\hline Managerial Economics & Operations Management \\
\hline Marketing Management & System Analysis and Design \\
\hline Java Programming & Database Management Systems \\
\hline Practical & Practical \\
\hline Java Programming Lab & DBMS Lab \\
\hline Third Semester & Fourth Semester \\
\hline Financial Services Management & Corporate Strategy \& Policy \\
\hline Enterprise Resource Planning and Business & Financial Accounting (ERP) \\
\hline Software Project Management & Elective - II (Choose any one paper) \\
\hline Elective-I (Select any one group) & Human Resource Management \\
\hline Group 1: Human Resource & Sales and Distribution \\
\hline Human Resource Planning and Development & Materials Management \\
\hline Human Resource Payroll & Production Planning \\
\hline Group 2: Production and Operations Management & System Administration \\
\hline Materials Management & Practical \\
\hline Production Planning and Control & Financial Accounting (ERP) Lab \\
\hline Group 3: Marketing & Elective Lab \\
\hline Sales and Distribution & Dissertation \\
\hline Customer Relationship Management & Seminar and Project Progress Report \\
\hline Group 4: Technical/Administration & Comprehensive viva voce \\
\hline \multicolumn{2}{|l|}{ Database Administration } \\
\hline \multicolumn{2}{|l|}{ Operating Systems } \\
\hline \multicolumn{2}{|l|}{ Practical } \\
\hline \multicolumn{2}{|l|}{ Business Application Programming Lab } \\
\hline \multicolumn{2}{|l|}{ Summer Training Project } \\
\hline Minor Project Work & \\
\hline
\end{tabular}


Table 2: The Specialization and Placement Details of the First Graduating Class - Year 2008)

\begin{tabular}{|l|c|c|}
\hline ERP Specialization & No. of Students & No. of Students Placed \\
\hline $\begin{array}{l}\text { Human } \\
\text { Resource }\end{array}$ & 07 & 06 \\
\hline $\begin{array}{l}\text { Material } \\
\text { Management }\end{array}$ & 12 & 10 \\
\hline $\begin{array}{l}\text { Sales and } \\
\text { Distribution }\end{array}$ & 18 & 14 \\
\hline $\begin{array}{l}\text { Financial } \\
\text { Accounting and } \\
\text { Controlling }\end{array}$ & 06 & 06 \\
\hline $\begin{array}{l}\text { System } \\
\text { Administration }\end{array}$ & 11 & 09 \\
\hline
\end{tabular}

Table 3: Program Layers Description

\begin{tabular}{|c|c|}
\hline Program Layers & Description \\
\hline Layer 1 & Management Practices Impinging upon Managers \\
\hline Layer & $\begin{array}{l}\text { Technology and Innovation Management in Internet } \\
\text { Economy }\end{array}$ \\
\hline Layer & Software Engineering Principles and Practices \\
\hline Layer & $\begin{array}{l}\text { Modern Programming Language Concepts and } \\
\text { Interpretations }\end{array}$ \\
\hline Layer & $\begin{array}{l}\text { Enterprise wide Analysis using Databases and Data } \\
\text { Warehousing Techniques }\end{array}$ \\
\hline Layer & Software Project Management in Networking environment \\
\hline Layer & $\begin{array}{l}\text { Enterprise Resource Planning (ERP) and Logistics } \\
\text { Management }\end{array}$ \\
\hline Layer 8 & $\begin{array}{l}\text { e-Biz : Harnessing Opportunities in e-Market } \\
\text { Places }\end{array}$ \\
\hline
\end{tabular}

